\title{
Luomuperunan tuotantoketjun kehittäminen Pohjois-Pohjanmaalla
}

\author{
Lea Hiltunen ${ }^{1)}$, Kirsi Korhonen ${ }^{1)}$, Virpi Vorne ${ }^{1)}$, Yeshitila Degefu ${ }^{1)}$, Elina Virtanen ${ }^{1)}$, Toivo Muilu ${ }^{1)}$, \\ Maija-Liisa Tausta-Ojala ${ }^{2)}$ \\ ${ }^{1)}$ Luonnonvarakeskus Oulu, Paavo Havaksen tie 3, 90014 Oulun yliopisto, etunimi.sukunimi@luke.fi \\ ${ }^{2)}$ ProAgria Oulun maa- ja kotitalousnaiset, maija-liisa.tausta-ojala@maajakotitalousnaiset.fi
}

Pohjois-Pohjanmaa on tärkeää perunantuotantoaluetta ja luontaisten olosuhteiden puolesta se sopisi hyvin myös luomuperunan tuotantoon. Luomuperunan viljelyssä on kuitenkin monia kriittisiä kohtia. Tutkimuksen tavoitteena oli löytää luomuperunan tautien hallintaan, lannoitukseen ja lajikevalintaan uusia ratkaisuja, joiden avulla luomuperunantuotannon varmuus ja kannattavuus sekä luomuperunan laatu paranisivat. Lisäksi selvitettiin luomuperunan kysyntää Pohjois-Pohjanmaan ammattikeittiöissä sekä alueen viljelijöiden kiinnostusta luomuperunan viljelyyn.

Vuonna 2016 ammattikeittiöille tehtiin sähköinen kysely luomuperunan käytöstä ja käyttöä rajoittavista tekijöistä. Suurin osa kyselyyn vastanneista $(n=33)$ kertoi joko jo käyttävänsä erilaisia luomuperunatuotteita tai olevansa kiinnostunut niiden käytöstä. Käyttöä rajoittivat erityisesti huono saatavuus, saatavuuden vaihtelu sekä hinta. Kyselyn mukaan luomuperunasta ja luomuperunatuotteista oltiin pääsääntöisesti valmiita maksamaan vain 1-5\% enemmän kuin tavanomaisista perunatuotteista. Vuosina 2016 ja 2017 viljelijöille tehtyjen kyselyiden perusteella kiinnostus luomuperunanviljelyyn on vähäistä. Vain $6 \%$ tavanomaisen perunan viljelijöistä $(n=48)$ ja $11 \%$ luomutuottajista $(n=44)$ oli selvästi kiinnostunut luomuperunanviljelystä. Tavanomaisen perunan viljelijät pitivät suurimpina esteinä luomuperunantuotantoon siirtymiselle kasvinsuojelun vaikeutta, huonoa satotasoa sekä alhaista hintaa. Luomuviljelijät puolestaan näkivät haasteina kasvinsuojelun lisäksi muuttuvat säädökset, kysynnän epävarmuuden sekä puutteelliset jakeluverkostot.

Lajikkeita, lannoitusohjelmia ja -tasoja sekä biologisia torjunta-aineita vertailtiin luomuperunaviljelmillä toteutetuissa ruutukokeissa vuosina 2016 ja 2017. Kasvukausi 2016 oli luomuperunatuotannon kannalta epäsuotuisa. Sademäärä oli suuri ja olosuhteet perunaruton kehittymiselle otolliset. Märkyyden ja aikaisin ilmaantuneen perunaruton vuoksi satomäärät jäivät pieniksi (noin $10 \mathrm{t} \mathrm{ha}^{-1}$ ). Ulkoiselta laadultaan sato oli hyvää, mutta kauppakelpoisen sadon osuutta (65\%) vähensi pienten mukuloiden suuri osuus. Lajikkeiden (Marabel, Solist, Albatros, YK) väliset satoerot olivat suuria. Lihaluujauhopohjainen lisälannoitus (Perus-Viljo NPK 7-4-1 tai Erikois-Viljo NPK 8-4-8 tasoilla 30 tai $60 \mathrm{~kg} \mathrm{~N} \mathrm{ha}^{-1}$ ) ei antanut lisähyötyä verrattuna viherlannoitukseen. Perunaruton ohella muita tauteja esiintyi vähän eivätkä testauksessa olleet biotorjuntavalmisteet (Rhizovital 42/FZB24, Rhizocell, Prestop, Greenstim, Streptomyces-kanta 272) vaikuttaneet sadon määrään tai laatuun.

Vuonna 2017 testattujen lajikkeiden (Marabel, Solist, Colomba, Albatros) välillä oli eroa alkukehityksen nopeudessa, rutonkestävyydessä, sadon laadussa ja määrässä. Lannoituksen lisäys (ErikoisViljo NPK 8-4-8 tasoilla 30 tai $60 \mathrm{~kg} \mathrm{~N} \mathrm{ha}^{-1}$ ) lisäsi kokonaissatoa, mutta toisaalta vähensi kauppakelpoisen sadon osuutta. Biotorjunta-ainekäsittelyt nopeuttivat alkukehitystä, mutta eivät vaikuttaneet tautien esiintymiseen eivätkä sadon määrään ja laatuun.

Luomuperunan saatavuuden paraneminen vaatii toimenpiteitä koko ruokaketjussa. Erityisen tärkeää on luomutietouden lisääminen ja ymmärryksen parantaminen luomuperunan hintaan vaikuttavista tekijöistä. Kiinnostusta luomuperunan viljelyyn voidaan lisätä muun muassa kehittämällä tehokkaampia viljelymenetelmiä, luomalla uusia jakelukanavia sekä parantamalla luomuviljelyä koskevaa neuvontaa.

Asiasanat: Luomuperuna, biologinen torjunta, lannoitus, ammattikeittiö, kyselytutkimus 


\section{Johdanto}

Peruna on yksi käytetyimmistä luomuperuselintarvikkeista. Sen kysyntä on kasvanut voimakkaasti mm. ammattikeittiöissä ja teollisuuden valmisruokapuolella. Suomessa luomuperunan tuotantoala on kuitenkin vain alle kolme prosenttia perunan koko viljelyalasta (Luke 2017a) eikä luomuperunan tarjonta vastaa aina sen kysyntää. Pohjois-Pohjanmaan maakunnassa toteutettujen lähiruokaan ja elintarvikealaan liittyvien hankkeiden mukaan ammattikeittiöissä on selvää kysyntää paikallisille tuotteille (esim. Kotavaara ym. 2014, Korhonen \& Muilu 2015). Lähellä tuotettu peruna on yksi yleisimmistä ammattikeittiöiden käyttämistä lähiruokatuotteista, mutta luomuperunan saatavuuden on arvioitu olevan varsin heikko. Tällä hetkellä lähiruoka näyttää olevan vielä luomutuotteita kysytympää, mutta jotkut keittiöt haluavat panostaa nimenomaan luomuun.

Pohjois-Pohjanmaan alueella tuotettiin vuonna 2017 lähes neljäsosa maan ruokaperunasadosta (Luke 2017b). Suomen maakunnista eniten luomualaa on Pohjois-Pohjanmaalla, joten alueella on myös hyvät edellytykset luomuperunan tuotantoon. Luomuperunan viljelyssä on kuitenkin monia kriittisiä kohtia. Luomuperunan tuotannon lisääminen edellyttää uusien ratkaisujen löytämistä tuotantoteknisiin ongelmakohtiin kuten lannoituksen optimointiin ja kasvitautien hallintaan, joilla taataan laadultaan tasaisen ja käyttötarkoitukseen sopivan perunan tuottaminen.

Kasvitautien hallinta on yksi keskeisimmistä luomuperunan tuotannon ongelmista. Aiemmissa tutkimuksissa vaikeimmin hallittaviksi luomuperunan taudeiksi Suomessa ovat osoittautuneet perunaruton (Phytophthora infestans) ohella perunaseitti (Rhizoctonia solani) ja perunarupi (Streptomyces spp.) (Hannukkala ym. 2006, Hannukkala 2011, Nuutila ym. 2014). Näiden lisäksi tyvi- ja märkämädän (Dickeya- ja Pectobacterium -bakteerit) aiheuttamat ongelmat ovat lisääntyneet ja yleistyneet viime vuosina (Degefu \& Virtanen 2015). Luomuperunan tuotannossa kasvitautien hallinta perustuu lajikevalintaan, hyvänlaatuisen siemenperunan käyttöön sekä riittävään viljelykiertoon. Varteenotettava vaihtoehto voisivat olla myös biologiset torjunta-aineet, joita on markkinoilla runsaasti (Tuomola \& Valkonen 2013, Bernard ym. 2014). Käytön edellytyksenä on kuitenkin niiden tehokkuuden selvittäminen pohjoisissa oloissamme.

Luomuperunan tuotannossa lajikevalinnan tärkeimmät kriteerit ovat aikaisuus ja rutonkestävyys. Koska lajikkeiden menestymistä luomuviljelyssä ei voida tietää tavanomaisessa viljelyssä tehtyjen lajikekokeiden perusteella, tulee lajikkeet testata luomuviljelyn olosuhteissa, jotta saadaan tietoa yksittäisten lajikkeiden sopivuudesta luomuviljelyyn.

Luonnonmukaisessa tuotannossa perunan lannoituksen perusta on monivuotinen palkokasveja sisältävä viljelykierto sekä ravinteiden kierrättäminen käyttämällä luonnonmukaisessa tuotannossa syntyneitä eloperäisiä eli orgaanisia lannoitteita kuten karjanlantaa ja kompostia. Luonnonmukaisessa tuotannossa lannoitevalmisteet ja maanparannusaineet, jotka on lueteltu toimeenpanoasetuksessa ja jotka täyttävät lannoitevalmisteita koskevan lainsäädännön vaatimukset (Evira 2017), ovat sallittuja. Täydennyslannoitusta voidaan käyttää, jos riittävää ravinnemäärää ei saavuteta viljelykierrolla tai omasta tai muista luomuyksiköistä peräisin olevalla eloperäisellä aineksella. Lisälannoituksen käyttötarve ja sen perustelut tulee kirjata viljelysuunnitelmaan tai lohkokohtaisiin muistiinpanoihin.

Tämän tutkimuksen tavoitteena oli löytää luomuperunan tautien hallintaan, lannoitukseen ja lajikevalintaan uusia ratkaisuja, joiden avulla luomuperunantuotannon varmuus ja kannattavuus sekä luomuperunan laatu paranisivat. Lisäksi selvitettiin luomuperunan kysyntää Pohjois-Pohjanmaan ammattikeittiöissä sekä alueen viljelijöiden kiinnostusta luomuperunan viljelyyn.

\section{Materiaalit ja menetelmät}

Luomuperunan kysyntää ja tuotantopotentiaalia selvitettiin vuosina 2016-2017 Pohjois-Pohjanmaan alueella toteutetuilla kyselyillä. Ammattikeittiöiden perunan käyttöön ja hankintaan liittyvistä käytännöistä ja tarpeista sekä luomuperunantuotannon kehittämiseen liittyvistä mielipiteistä saatiin yhteensä 
33 vastausta. Perunantuottajien ja luomutuottajien näkemyksiä luomuperunantuotantoa estävistä tekijöistä ja kiinnostuksesta sitä kohtaan saatiin yhteensä 109 vastausta (61 perunantuottajat, 48 luomutuottajat). Kyselyaineistoja käsiteltiin kuvailevin tilastotieteen menetelmin muuttujien jakaumia tarkastelemalla. Muuttujien välisiä riippuvuuksia ja ryhmien eroja analysoitiin ristiintaulukoinnilla, varianssianalyysillä ja Kruskal-Wallisin testillä.

Biologisten torjunta-ainekäsittelyiden tehokkuutta luomuperunan kasvitautien hallintaan sekä lisälannoituksen vaikutusta sadon määrään ja laatuun selvitettiin luomutiloilla toteutetuissa kenttäkokeissa kesällä 2016 Siikajoella ja 2017 Limingassa. Vuonna 2016 kokeet istutettiin toukokuun lopussa ja nostettiin elokuun puolivälissä. Vuonna 2017 istutus tehtiin kesäkuun alussa ja nosto syyskuun alussa. Kasvukauden aikaiset hoitotoimenpiteet tehtiin koneellisesti tilan käytäntöjen mukaan. Kasvustoista havainnoitiin taimettumista ja kasvitautien oireita. Sadonkorjuun jälkeen sato punnittiin, lajiteltiin kokoluokkiin ja sadossa esiintyvien tauti- ja muiden vioitusten määrä arvioitiin.

Biotorjunta-ainekokeessa koejärjestelynä oli neljä toistoa sisältävä satunnaistettujen täydellisten lohkojen malli (ruutukoko 5 m x 3,2 m). Siemenperunana käytettiin Opera-lajiketta, joka kestää hyvin perunaruttoa, mutta on altis mm. perunaseitille ja -ruvelle. Vuoden 2016 siemenperuna oli esiperussiemenluokkaa, kun taas vuoden 2017 siemenperuna oli sertifioimatonta erää ja sisälsi runsaasti perunaseittiä. Näin haluttiin varmistaa riittävä tautitartunta biotorjunta-aineiden tehon toteamiseksi. Testattavia biotorjunta-aineita olivat RhizoVital42 (Bacillus amyloliquefaciens), Rhizocell (B. amyloliquefaciens ja hiivauute), Prestop (Gliocladium catenulatum), kanta 272 (Streptomycessädebakteeri) ja Greenstim (glysiinibetaiini). Verranteena käytettiin vesikäsittelyä. Vuonna 2016 lukuun ottamatta Greenstim-käsittelyä peittaus tehtiin istutuksen yhteydessä ruiskuttamalla vaossa olevat siemenperunat reppuruiskulla juuri ennen vaon peittämistä. Greenstim-käsittely tehtiin kasvustoruiskutuksena mukulanmuodostuksen alkuvaiheessa. Vuonna 2017 osa peittauskäsittelyistä tehtiin istutuksen yhteydessä kuten vuonna 2016 ja osa ennen istutusta sumutuspeittauksena rullapöydällä tai upotuskäsittelynä.

Lannoitus- ja lajikekokeet toteutettiin neljä toistoa sisältävinä kaistakokeina. Vuonna 2016 (ruutukoko $4 \mathrm{~m} \mathrm{x} \mathrm{1,6} \mathrm{m)} \mathrm{oli} \mathrm{testattavana} \mathrm{neljä} \mathrm{lajiketta} \mathrm{(Marabel,} \mathrm{Solist,} \mathrm{Albatros} \mathrm{ja} \mathrm{YK)} \mathrm{ja} \mathrm{kaksi} \mathrm{eri} \mathrm{liha-}$ luujauhopohjaista lisälannoitetta (Perus-Viljo NPK 7-4-1 ja Erikois-Viljo NPK 8-4-8), joista molemmista oli kaksi lannoitustasoa (30 ja $60 \mathrm{~kg} \mathrm{~N} \mathrm{ha}^{-1}$ ). Vuoden 2017 kokeissa (ruutukoko $5 \mathrm{~m} \mathrm{x} \mathrm{1,6} \mathrm{m)}$ testattavana oli Marabel-, Solist-, Colomba- ja Albatros-lajike sekä Erikois-Viljo -lannoitteen kaksi lisälannoitustasoa (30 tai $60 \mathrm{~kg} \mathrm{~N} \mathrm{ha}^{-1}$ ). Kontrolli- eli perustasona oli tilan oma viherlannoitus, joka vuonna 2016 oli virna-kaura-persianapila-italianraiheinä -seos ja vuonna 2017 monivuotinen apilanurmi.

Kenttäkokeista saatu data analysoitiin varianssianalyysillä käyttäen SAS 9.4 -ohjelmaa (SAS Institute Inc., Cary, USA). Parittaisia eroja vertailtiin Tukeyn testin avulla.

Alustavissa testeissä selvitettiin perunaruttoa aiheuttavan Phytophthora infestans -patogeenin oireettoman eli piilevän tartunnan määrittämistä siemenperunasta DNA-pohjaisen menetelmän avulla (Hussain ym. 2005, Llorente ym. 2010). Testauksia varten DNA eristettiin joko suoraan perunan mukulan kuorimehusta tai herneliemessä tehdystä rikasteesta ja taudinaiheuttaja tunnistettiin kvantitatiivisella Real Time PCR (qPCR) -menetelmällä.

\section{Tulokset ja tulosten tarkastelu}

Luomuperunan kysyntää ja tuotantopotentiaalia koskevaan kyselyyn vastanneet 33 ammattikeittiötä edustivat melko laajasti maakuntaa, sillä vastauksia tuli yhteensä 16 eri paikkakunnalta PohjoisPohjanmaalta. Noin puolet vastanneista oli yksityisiä toimijoita $(n=17)$ ja reilu 40 prosenttia julkisia toimijoita (7 kuntaa ja 7 kuntayhtymää). Lisäksi kaksi vastaajaa edusti muuta hallintomuotoa. Henkilökunnan määrä kyselyyn vastanneissa keittiöissä oli yleisimmin 2-4 henkeä $(n=16)$ tai 5-9 henkeä $(\mathrm{n}=11)$. 
Yli kaksi kolmasosaa vastanneista ammattikeittiöistä ilmoitti käyttävänsä Pohjois-Pohjanmaalla tuotettua perunaa tai perunajalosteita. Perunan ja perunatuotteiden valinnassa tärkeimpinä tekijöinä pidettiin tuotteen laatua, makua ja joustavaa toimitusta. Vastaajilla oli kiinnostusta käyttää erilaisia luomuperunatuotteita, vaikka niitä ei vielä käytetty. Eniten kiinnostivat kuorittu annosperuna sekä luomukuoriperuna ja muut tuoreperunatuotteet. Vähiten kiinnostusta herättivät puolestaan kuivatuotteet. Kiinnostusta perusteltiin muun muassa ekologisilla syillä ja yrityksen konseptiin sopivuudella. Toisaalta luomuperunan ja -perunatuotteiden käytön kannalta rajoittavimmiksi tekijöiksi koettiin huono saatavuus myyntipaikassa, saatavuuden vaihtelu sekä hinta. Myös aiemmissa tutkimuksissa suurimpana ongelmana liittyen luomuperunan käyttöönottoon ammattikeittiöissä on nähty olevan muun muassa luomuperunan saatavuus ja laadun vaihtelut, mutta myös ammattikeittiöihin sopivien lajikkeiden puuttuminen (Nuutila ym. 2013, Kotavaara ym. 2014). Toisaalta on huomioitava, että maakunnan vahvan perunantuotanto-osaamisen myötä tavanomaisesti tuotettua perunaa pidetään laadultaan hyvänä, joten näin ollen tarvetta luomuperunalle ei välttämättä nähdä.

Ammattikeittiöiden maksuhalukkuus luomusta on alhainen. Luomuperunasta ja luomuperunatuotteista ollaan pääsääntöisesti valmiita maksamaan saman verran tai 1-5\% enemmän kuin tavanomaisista perunatuotteista. Vain kahdesta neljään vastaajaa olisi valmis maksamaan erilaisista luomuperunatuotteista 6-10\% enemmän. Ammattikeittiöt pitivät kuitenkin luomuperunantuotantoa kaiken kaikkiaan varsin tärkeänä, ja tärkeimpänä kehittämisen osa-alueena nähtiin saatavuuden varmistaminen.

Kyselyyn vastanneista perunantuottajista suurin osa $(n=37)$ oli ruokaperunantuottajia. Lisäksi vastaajajoukossa oli mukana muun muassa siemenperunan ja ruokateollisuusperunan tuottajia. Vastaajista 11 ilmoitti tuottavansa luomuperunaa ja yksi oli siirtymävaiheessa. Tuotanto oli suurimmalla osalla kuitenkin varsin pienimuotoista tuotantopinta-alan ollessa alle yhden hehtaarin. Vain 6 prosentilla perunantuottajista ja 11 prosentilla luomutuottajista oli selvää kiinnostusta luomuperunantuotantoa kohtaan (ne tuottajat, jotka eivät vielä tuottaneet luomuperunaa tai olleet siirtymävaiheessa). Hieman suurempi määrä ilmoitti olevansa kiinnostunut, jos olosuhteet tuotannolle paranevat. Suurimpina haasteina perunantuottajat näkivät kasvinsuojelun, riittävän satotason saavuttamisen sekä hintatasovaatimukset. Luomutuottajien mukaan suurimpia haasteita ovat sen sijaan maatalouspolitiikan epävarmuus/muuttuvat säädökset, kasvinsuojelu, epävarmuus kysynnän jatkuvuudesta sekä jakeluverkoston puute. Muita vastauksissa esille tulleita syitä olivat muun muassa ikä sekä sopivien maalajien ja koneiden puute.

Kasvukausi 2016 oli Pohjois-Pohjanmaalla luomuperunatuotannon kannalta epäsuotuisa. Sademäärä oli suuri ja olosuhteet perunaruton kehittymiselle otolliset. Märkyyden ja aikaisin ilmaantuneen perunaruton vuoksi satomäärät jäivät kenttäkokeissa pieniksi, noin $10 \mathrm{t} \mathrm{ha}^{-1}$. Ulkoiselta laadultaan sato oli hyvää, mutta kauppakelpoisen sadon osuutta (65\%) vähensi pienten $(<30 \mathrm{~mm}$ ) mukuloiden suuri osuus. Kasvukausi 2017 oli puolestaan perunan kasvun kannalta suotuisa ja kokonaissadot olivat yli kaksinkertaisia edelliseen vuoteen verrattuna.

Vuonna 2016 biotorjuntavalmisteet eivät vaikuttaneet sadon määrään tai laatuun. Vuonna 2017 kaikki biotorjunta-ainekäsittelyt nopeuttivat taimettumista vesipeittaukseen (kontrolli) nähden. Käsittelyt lisäsivät myös hieman kokonaissatoa, mutta sadonlisäys ei ollut tilastollisesti merkitsevä. Perunaseitin oireita esiintyi runsaasti johtuen siemenperunan mukana tulleesta tartunnasta sekä taudin kehittymisen kannalta suotuisista oloista. Versolaikkuisten kasvien osuus kasvustossa oli keskimäärin 63\% ja perunaseittisten mukuloiden osuus sadossa 30\%. Perunaseitin lisäksi sadoissa esiintyi jonkin verran perunarupea sekä vähäisiä määriä kuiva- ja bakteerimätää. Biotorjunta-ainekäsittelyt eivät vaikuttaneet näiden tautien esiintymiseen tai ankaruuteen. Biotorjunta-ainekäsittelyiden tehoon vaikuttavat itse torjuntamikrobin lisäksi myös tautipaine sekä ympäristötekijät mukaan lukien sääolot ja maaperän kemialliset, fysikaaliset ja biologiset ominaisuudet. Tautipaineen ollessa suuri, kuten perunaseitin osalta vuonna 2017, biologisten torjunta-aineiden teho voi olla riittämätön. Siksi testauksia tulisikin tehdä erilaisten tautipaineiden vallitessa. Kasvukaudella 2016 koealue kärsi märkyydestä ja maaperän olosuhteet olivat epäsuotuisat torjuntamikrobien toiminnan kannalta. Biologisten torjunta-aineiden 
olosuhderiippuvuuden ymmärtämiseksi olisi tärkeää, että testauksia tehtäisiin useilla eri koepaikoilla ja usean vuoden ajan.

Piilevän perunaruton tunnistamiseen käytetty qPCR-menetelmä toimi alustavissa testauksissa luotettavasti ja antoi viitteitä siitä, että pienetkin taudinaiheuttajan määrät mukulassa on mahdollista rikastaa havaittavalle tasolle. Menetelmä tulee kuitenkin vielä validoida käyttäen luontaisesti saastuneita mukuloita. Koska maa on mukuloiden ohella merkittävä perunaruttotartunnan lähde, menetelmän soveltamista perunaruton aiheuttajan tunnistamiseen maanäytteistä voitaisiin myös selvittää.

Vuonna 2016 lannoite- ja lajikekokeessa lajikkeiden (Marabel, Solist, Albatros, YK) väliset satoerot olivat suuria. Lihaluujauhopohjainen lisälannoitus (Perus-Viljo NPK 7-4-1 tai Erikois-Viljo NPK 8-4-8

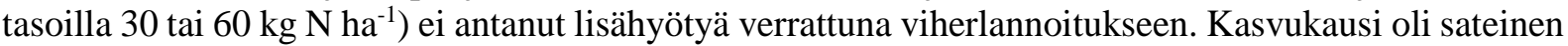
ja kasvustot kärsivät liiallisesta märkyydestä, mikä vaikeuttaa vuoden 2016 tulosten tulkintaa. Tämän vuoksi tulosten tulkinnassa keskitytään vuoden 2017 satoon.

Vuoden 2017 lajike- ja lannoituskokeen lajikkeista aikaiset Solist ja Colomba taimettuivat keskiaikaista Marabelia ja myöhäistä Albatrosia aikaisemmin. Colomban taimettumisprosentti oli suurin (97\%), Solistin 93\% sekä Albatrossin ja Marabelin 91\%. Lehtiruttoa havaittiin ensimmäisenä aikaisissa lajikkeissa. Lannoitustaso ei vaikuttanut rutto-oireiden ilmaantumiseen. Elokuun loppuun mennessä Solistin ja Colomban kasvustosta noin puolet oli ruton tuhoamaa, kun vastaavana aikana Marabelista oli tuhoutunut 25\% ja Albatros-lajikkeesta vasta 10\%. Sadonkorjuun aikaan aikaiset lajikkeet olivat lähes täysin ruton tuhoamia, Marabelista oli tuhoutunut 85\% ja Albatros-lajikkeesta hieman yli 50\%.

Vuonna 2017 Marabelin ja Solistin sadot olivat noin $23 \mathrm{t} \mathrm{ha}^{-1}$, Colomban $25 \mathrm{t} \mathrm{ha}^{-1} \mathrm{ja}$ Albatrossin hieman alle $20 \mathrm{t} \mathrm{ha}^{-1}$. Albatrossin satotaso jäi kokeessa alhaiseksi, koska kasvusto ei ehtinyt tuleentua. Yleisesti ottaen lisälannoitus paransi hieman satotasoa. Suurempi lannoitustaso (60 $\mathrm{kg} \mathrm{N} \mathrm{ha}^{-1}$ ) lisäsi kokonaissatoa $(p<0.05)$ verrattuna pelkkään viherlannoitukseen, sen sijaan kauppakelpoisessa sadossa ei ollut eroja lannoitustasojen välillä (Kuva 1). Kun lannoitusvaikutusta tarkasteltiin yli lajikkeiden, suurempi lannoitustaso lisäsi ylisuurten perunoiden (yli 60 mm) määrää.
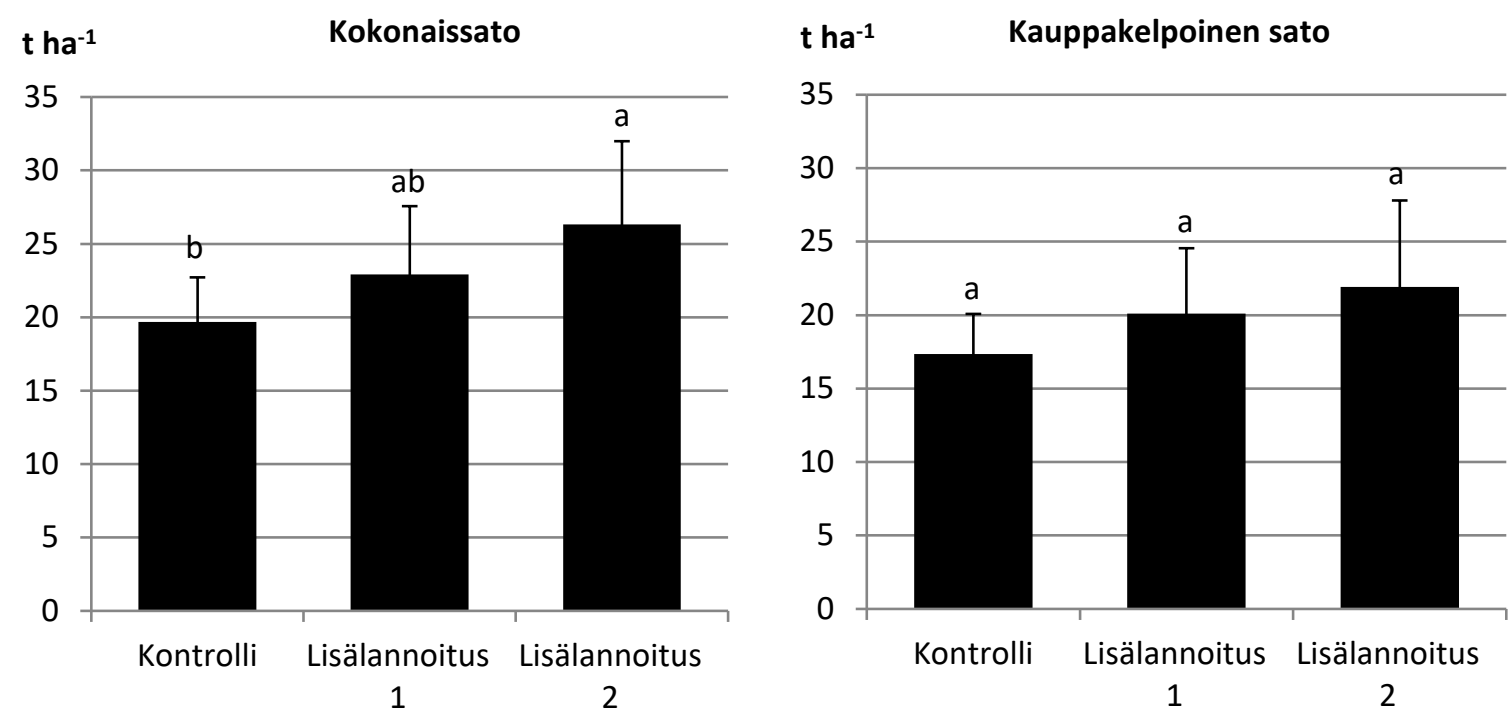

Kuva 1. Lihaluujauhopohjaisen lisälannoituksen vaikutus kokonais- ja kauppakelpoiseen satoon vuonna 2017. Lisälannoitustason 1 (viherlannoitus + lisälannoitus) typen laskennallinen määrä oli $30 \mathrm{~kg} \mathrm{ha}^{-1}$ ja lisälannoitustason 2 (viherlannoitus + lisälannoitus) $60 \mathrm{~kg} \mathrm{ha}^{-1}$. Kontrollina pelkkä viherlannoitus. Eri kirjaimilla merkityt keskiarvot eroavat toisistaan merkitsevästi ( $p<0.05$, Tukey). 


\section{Johtopäätökset}

Luomuperunan saatavuuden paraneminen Pohjois-Pohjanmaalla vaatii luomutietoisuuden levittämistä yleisesti ja toimenpiteitä koko ruokaketjussa. Luomutietouden lisääminen erityisesti keittiöissä on tärkeää ja ymmärrystä eri hintatasovaatimuksista täytyy parantaa. Luomuperunan korkeilla tuotantokustannuksilla ei hintaa voida laskea kovinkaan lähelle tavanomaisen perunan hintatasoa, joka on jo nykyisellään ajettu hyvin alas. Kyselyiden perusteella näytti siltä, että perunantuottajat eivät pidä luomuperunantuotantoa yhtä tärkeänä kuin luomutuottajat ja ammattikeittiöt, joten luomuperunantuotannosta täytyy saada myös tuottajien keskuudessa kiinnostavampaa.

Biotorjunta-ainekäsittelyillä ei ollut vaikutusta peruna tautien esiintymiseen ja ankaruuteen. Niiden tehosta erilaisista olosuhteissa olisi hyvä saada lisää tietoa. Näiden kokeiden perusteella luomuperunatuotannon taudinhallintaa ei voi perustaa biologisten torjunta-aineiden varaan, vaan on tärkeää yhdistää useampia keinoja, kuten tautivapaan siemenperunan käyttö, monivuotinen viljelykierto ja kestävien lajikkeiden valinta. Piilevän perunaruton tunnistaminen siemenperunassa qPCR-menetelmällä näyttää lupaavalta. Menetelmän käyttöönotolla olisi suuri merkitys siemenperunan laadun varmistamisessa ja perunarutonruton hallinnassa erityisesti luomuperunantuotannossa.

Lihaluujauhopohjaisella lisälannoituksella ei saatu oleellista hyötyä luomuperunantuotannossa. Lannoitustason nousu lisäsi pääasiassa suurten perunoiden osuutta sadossa. Täten lisälannoitus ei lisännyt kauppakelpoisen sadon määrää. Erilaisten lannoitteiden ja lannoitetasojen vaikutuksia lajikekohtaisiin sato-ominaisuuksiin tulisi edelleen selvittää, sillä kasvin oikea-aikainen ravinteiden saanti on luomuperunatuotannon yksi avainkysymyksistä.

\section{Kiitokset}

Luonnonvarakeskus Oulun ja ProAgria Oulun Maa- ja kotitalousnaisten toteuttama Luomuperunahanke sai rahoitusta Manner-Suomen maaseudun kehittämisohjelmasta 2014-2020 Pohjois-Pohjanmaan ELYkeskuksen kautta sekä yksityisrahoitusta seuraavilta tahoilta: Perunantuotannon tutkimus- ja kehityssäätiö, Marjatta ja Eino Kollin Säätiö, Oulun läänin talousseuran maataloussäätiö, Verdera Oy, Luonnosta Oy ja ProAgria Oulun Maa- ja kotitalousnaiset. Hankkeen toteutusta ovat tukeneet lisäksi Mikon luomuperuna ja luomuviljelijä Janne Pietilä.

\section{Kirjallisuus}

Bernard, E., Larkin, R.P., Tavantzis, S., Erich, M.S., Alyokhin, A. \& Gross, S.D. 2014. Rapeseed rotation, compost and biocontrol amendments reduce soilborne diseases and increase tuber yield in organic and conventional potato production systems. Plant and Soil 374: 611-627.

Degefu, Y. \& Virtanen, E. 2015. Tyvi- ja märkämätää aiheuttavat Dickeya ja Pectobacterium-lajit Suomessa. Tuottava Peruna 2: 22-24.

Evira 2017. Luonnonmukaiseen tuotantoon soveltuvat lannoitevalmisteet, "Luomulannoiteluettelo". https://www.evira.fi/globalassets/yhteiset/luomu/lannoite-ja-torjunta-aine/luomulannoiteluettelo.pdf

Hannukkala, A. 2011. Luomuperunan taudit ja niiden hallinta.

http://luomu.fi/materiaalit/01_Tietokortit/Hannukkala_Luomuperunan_kasvinsuojelu.pdf

Hannukkala, A., Lehtinen, A., Rahkonen, A., Kangas, A., Virtanen, E., Hannukkala, A. \& Huhta, H. 2006. Luomuperunan kasvitautien hallinta. Julkaisussa: Maataloustieteen Päivät 2006. Suomen Maataloustieteellisen Seuran julkaisuja no 21. ISBN 951-9041-49-4.

Hussain, S., Lees, A.K., Duncan, J.M. \& Cooke, E.L. 2005. Development of a species specific and sensitive detection assay for Phytophtora infestans and its application for monitoring of inoculum in tubers and soil. Plant Pathology 54: 373-382.

Korhonen, K. \& Muilu, T. 2015. Ruokaketjun alueellisen verkostomallin kehittäminen Oulun Eteläisen alueella. RuokaNET-hankkeen loppuraportti. Luonnonvara- ja biotalouden tutkimus 4/2016. 50 s.

Kotavaara, O., Korhonen, K., Miettinen, M., Lehtinen, U., Muilu, T., Juga, J. \& Rusanen, J. 2014. Lähi- ja luomuruoan saavutettavuus Pohjois-Pohjanmaalla. MTT Raportti 152. 104 s. 
Llorente, B., Bravo-Almonacid, F., Cvitanich, C., Orlowska, E., Torres, H.N., Flawia, M.M. \& Alonso, G.D. 2010. A quantitative real-time PCR method for in planta monitoring of Phytophtora infestans growth. Letters in Applied Microbiology 51: 603-610.

Luke 2017a. Luomusatotilasto. Helsinki. http://stat.luke.fi/luomusatotilasto

Luke 2017b. Satotilasto, Viljelykasvien sato alueittain. http://statdb.luke.fi/PXWeb/sq/a0ecb37a-0802-4911$\underline{\text { 8747-b16521bab758 }}$

Nuutila, J., Kankaala, A., Virtanen, E. \& Vorne, V. 2014. Luomuperunan laatu hallintaan - kasvua kulutukseen (SLUPElaatu). Maa- ja elintarviketalouden tutkimuskeskus MTT, Luomuinstituutti. $42 \mathrm{~s}$.

http://luomuinstituutti.fi/wp-content/uploads/sites/2/2014/04/Loppuraportti_Slupe_Luomuperuna_laatu_MTT_ 2013.pdf

Tuomola, J. \& Valkonen, J. 2013. Uusimmat käytännöt perunan kasvitautien torjunnassa. MTT Raportti 118. 40 s. ISBN 978-952-487-490-8. http://www.mtt.fi/mttraportti/pdf/mttraportti118.pdf 